\title{
Origin of enriched uranium contained in Japanese atmospheric deposits
}

\author{
Yoshikazu Kikawada ${ }^{1^{*}}$, Kohei Oda ${ }^{1}$, Masao Nomura ${ }^{2}$, Teruyuki Honda ${ }^{3}$, Takao $\mathrm{Oi}^{1}$, \\ Katsumi Hirose ${ }^{1}$, Yasuhito Igarashi ${ }^{4}$ \\ ${ }^{1}$ Department of Materials and Life Sciences, Sophia University, Tokyo, Japan; ${ }^{*}$ Corresponding Author: y-kikawa@sophia.ac.jp \\ ${ }^{2}$ Research Laboratory for Nuclear Reactors, Tokyo Institute of Technology, Tokyo, Japan \\ ${ }^{3}$ Atomic Energy Research Laboratory, Tokyo City University, Kawasaki, Japan \\ ${ }^{4}$ Meteorological Research Institute, Tsukuba, Japan
}

Received 30 September 2012; revised 28 October 2012; accepted 9 November 2012

\begin{abstract}
The chemical compositions of atmospheric deposits collected in Fukuoka, Japan, in 1964 and 2000 , which are known to have high ${ }^{235} \mathrm{U} /{ }^{238} \mathrm{U}$ uranium isotope ratio were determined. High uranium contents relative to that of continental crust were observed for the deposition samples in 1964 together with the high ${ }^{235} \mathrm{U} /{ }^{238} \mathrm{U}$ ratios, which indicated that the origin of uranium is fallout materials due to the large-scale 19611962 nuclear explosions conducted by US and former USSR. The deposits in $\mathbf{2 0 0 0}$ were mainly composed of dusts from the East Asia. This suggested that uranium with a high ${ }^{235} \mathrm{U} /{ }^{238} \mathrm{U}$ ratio in the deposits in 2000 has been transported as a component of mineral dust particles contaminated with nuclear debris from nuclear test sites from the East Asian deserts and arid regions by the prevailing wind.
\end{abstract}

Keywords: Atmospheric Deposit; Enriched Uranium; Uranium Isotope Ratio; Nuclear Test; Anthropogenic Radionuclides

\section{INTRODUCTION}

Uranium isotope ratios, especially ${ }^{235} \mathrm{U} /{ }^{238} \mathrm{U}$ ratio, do not fractionate substantially in the nature (within ca. $\pm 1 \%$ ) except those from natural nuclear reactors [1]. Anomalous ${ }^{235} \mathrm{U} /{ }^{238} \mathrm{U}$ ratios observed in environmental samples were thus recognized as a fingerprint of anthropogenic nuclear activities. Warneke et al. [2] reported high ${ }^{235} \mathrm{U} /{ }^{238} \mathrm{U}$ ratios for the Alpine ice core samples and archived herbage samples of IACR-Rothamsted, UK compared to the natural ratio in the 1950s and 1960s. Their observation suggests that uranium having anomalous isotope ratios had been emitted by nuclear test ex- plosions and had spread all over the world as fallout.

In the 1950s, Japan Meteorological Agency (JMA) started sampling atmospheric deposits in Japan and the measurement of anthropogenic radioactivity, especially for ${ }^{90} \mathrm{Sr},{ }^{137} \mathrm{Cs}$ and $\mathrm{Pu}$, for monitoring environmental pollution connected to nuclear activities [3]. The ${ }^{235} \mathrm{U} /{ }^{238} \mathrm{U}$ ratios in those samples, however, had never been measured. In 2006, we started the study on uranium isotope ratios recorded in the Japanese atmospheric deposits and found the anomalous ${ }^{235} \mathrm{U} /{ }^{238} \mathrm{U}$ ratios in the atmospheric deposits collected at Fukuoka located in the southwestern Japan, where the Asian mineral dusts event (Kosa) is observed frequently in springtime [4]. That was the first report on anomalous ${ }^{235} \mathrm{U} /{ }^{238} \mathrm{U}$ ratios obtained by direct measuring of atmospheric deposits, clarifying that mineral dusts containing enriched uranium have been transported to Japan by the prevailing westerly since 1960 s until today continuously, although an atmospheric nuclear test has never been conducted since 1982. In this study, we discuss the origin of such mineral dusts and enriched uranium contained in them based on the chemical compositions of the atmospheric deposits.

\section{EXPERIMENTAL}

\subsection{Samples}

The monthly atmospheric deposits at Fukuoka (Figure 1) collected in 1964 and 2000 by JMA were utilized in this study. Fukuoka is the largest city in the Kyushu Island located at southwest of the main island of Japan (Honshu). Those samples have been collected every month with rainwater using a stainless still open surface sampler with a surface area of $0.5 \mathrm{~m}^{2}$. The collected samples have been evaporated to dryness for the following analytical procedure. After the radioactivity measurements, they have been stocked at the Japanese Metrological Research Institute (MRI). We have already reported the ${ }^{235} \mathrm{U} /{ }^{238} \mathrm{U}$ ratios in the Fukuoka deposits 


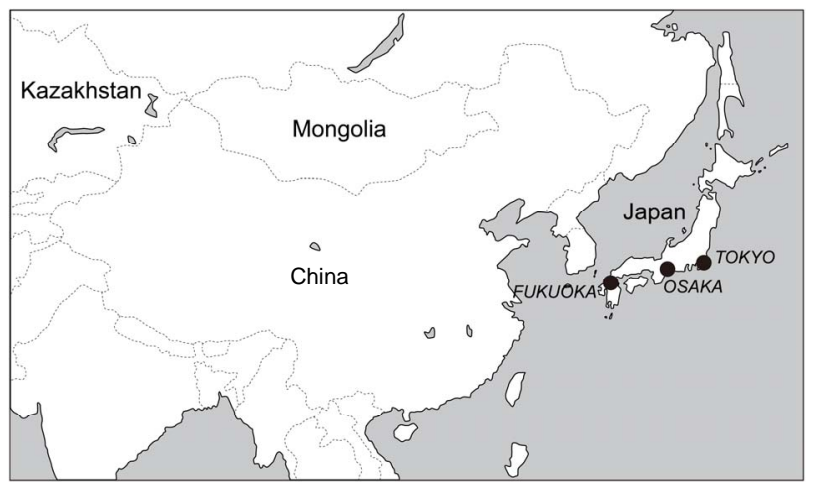

Figure 1. Map of East Asia.

collected in the month of March between 1964 and 2000 [4] (Figure 2). As seen in Figure 2, ${ }^{235} \mathrm{U}$ has been slightly enriched compared to the natural ratio through the period. It was suspected that enriched uranium was partially contained in fused silicates originating from nuclear test sites, because uranium in the acid-insoluble part is also enriched in ${ }^{235} \mathrm{U}$.

\subsection{Radioactivity Measurements}

Radioactivity of gamma-ray emitting nuclides in the deposits was measured by referring to the procedures established by MRI [3] at the Atomic Energy Research Laboratory, Tokyo City University using a 4096 channel multichannel analyzer (MCA7700, SEIKO EG \& G) with a high purity Ge detector (GMX-15190-P, ORTEC).

\subsection{Determination of Chemical Compositions}

The compositions for the major elements of the deposits were determined by ICP-OES and flame emission spectroscopy after digestion with $\mathrm{HF} / \mathrm{HCl}$ using sealed Teflon $^{\circledR}$ vessels based on the procedure described elsewhere [5]. The contents of rare earth elements (REEs) and actinides in the deposits were determined by nondestructive neutron activation analysis using the JRR-3 research reactor at Japan Atomic Energy Agency (JAEA) as a neutron source. The analytical procedure has been described elsewhere [6].

\section{RESULTS AND DISCUSSION}

The obtained chemical compositions and activities of radionuclides of the Fukuoka deposits are listed in Table 1. The yields of the deposits (as dry basis) are listed in Table 2 with some meteorological factors observed by Fukuoka District Meteorological Observatory. The mass yields (fluxes of atmospheric depositions) in 1964 were almost ten times larger than those in 2000. The high flux in 1964 supposedly resulted from the low urbanization level in the 1960s.

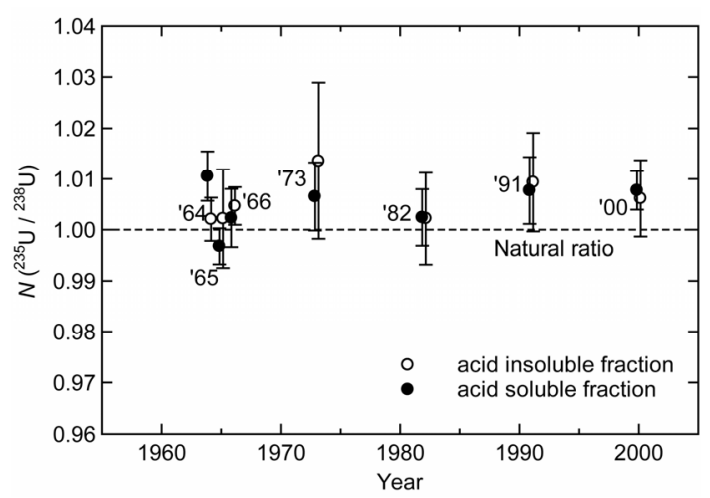

Figure 2. The ${ }^{235} \mathrm{U} /{ }^{238} \mathrm{U}$ isotope ratios in the Fukuoka deposits in the month of March between 1964 and 2000 [4]. $N\left({ }^{235} \mathrm{U} /{ }^{238} \mathrm{U}\right)$ denotes the normalized value of ${ }^{235} \mathrm{U} /{ }^{238} \mathrm{U}$ ratio in deposits against that in sea water. The open and closed circles show the insoluble and soluble fractions in $4 \mathrm{M} \mathrm{HNO}_{3}$ leaching treatments, respectively.

The monthly depositions of uranium calculated from its contents (Table 1) and the yields of the deposits (Table 2) are listed in Table 3 . The monthly uranium depositions in 1964 at Fukuoka are extremely large compared with those in 2000, a cause for which is larger mass depositions in 1964. The amount of enriched uranium deposited in Fukuoka in these days is thus smaller than in the $1960 \mathrm{~s}$, while the ${ }^{235} \mathrm{U} /{ }^{238} \mathrm{U}$ ratios in the $1960 \mathrm{~s}$ and in 2000s are comparable (Figure 2) [4].

In order to better understand causes of the high uranium deposition at Fukuoka in 1964, it is useful to examine other chemical constituents including major components such as silicate and iron and minor components such as Th and REEs. We examined the U/Si and Th/Si ratios in the deposits to clarify the effect of mineral dusts. The U/Si ratios in 1964 deposition samples, which ranged from $1.3 \times 10^{-5}$ to $3.0 \times 10^{-5} \mathrm{~g} / \mathrm{g}$, were higher than that in Nanjing loess $\left(0.74 \times 10^{-5} \mathrm{~g} / \mathrm{g}\right)$ [7] and in continental crust $\left(0.4 \times 10^{-5} \mathrm{~g} / \mathrm{g}\right)$ [8]. On the other hand, the $\mathrm{Th} / \mathrm{Si}$ ratios both in 1964 and 2000 , which ranged from $0.5 \times 10^{-5}$ to $1.7 \times 10^{-5} \mathrm{~g} / \mathrm{g}$, were similar to the crustal value $\left(1.3 \times 10^{-5} \mathrm{~g} / \mathrm{g}\right)$ and lower than that in the Nanjing loess $\left(4 \times 10^{-5} \mathrm{~g} / \mathrm{g}\right)$. The U/Si and $\mathrm{Th} / \mathrm{Si}$ ratios in deposition samples revealed that uranium was highly concentrated in the deposits of 1964 compared with that in mineral dusts, suggesting that sources of chemical constituents including uranium in the deposition in 1964 differed from that in 2000 .

The REE patterns for the deposits normalized with Leedey chondrite $[9,10]$ are shown in Figure 3. The profile through the light to middle REEs seems different between in 1964 and 2000. Figure 4 shows the Th/Sc$\mathrm{La} / \mathrm{Lu}$ diagram for the Fukuoka deposits. The Fukuoka deposits in 2000 and 1964 are plotted in quite different regions in the diagram. This difference is probably due to 
Table 1. (a) Contents of elements and radioactivity for Fukuoka deposits collected in 1964; (b) Contents of elements and radioactivity for Fukuoka deposits collected in 2000.

(a)

\begin{tabular}{|c|c|c|c|c|c|c|}
\hline 1964 & Jan & Feb & Mar & Apr & May & Jun \\
\hline \multicolumn{7}{|l|}{$(\mathrm{mg} / \mathrm{g})$} \\
\hline $\mathrm{Si}$ & 232 & 144 & 203 & 198 & 201 & 205 \\
\hline $\mathrm{Al}$ & 54.0 & 52.7 & 68.6 & 66.0 & 68.6 & 68.0 \\
\hline $\mathrm{Fe}$ & 38.2 & 31.4 & 50.8 & 43.8 & 47.1 & 39.8 \\
\hline $\mathrm{Mg}$ & 31.2 & 25.9 & 34.3 & 30.2 & 34.5 & 31.4 \\
\hline $\mathrm{Ca}$ & 70.8 & 40.3 & 58.2 & 60.1 & 55.4 & 56.3 \\
\hline $\mathrm{Na}$ & 25.0 & 15.9 & 37.1 & 37.3 & 27.1 & 32.1 \\
\hline $\mathrm{K}$ & 15.5 & 17.5 & 15.8 & 16.4 & 19.6 & 17.8 \\
\hline $\mathrm{Ti}$ & 3.2 & 2.5 & 4.4 & 4.0 & 3.7 & 3.4 \\
\hline $\mathrm{Mn}$ & 0.9 & 0.6 & 2.7 & 1.3 & 0.9 & 0.8 \\
\hline \multicolumn{7}{|l|}{$(\mu \mathrm{g} / \mathrm{g})$} \\
\hline $\mathrm{Sc}$ & $6.9 \pm 0.1$ & $11.6 \pm 0.2$ & $9.9 \pm 0.2$ & $9.5 \pm 0.2$ & $9.4 \pm 0.2$ & $9.8 \pm 0.2$ \\
\hline $\mathrm{La}$ & $10.7 \pm 0.8$ & $17.5 \pm 0.9$ & $15.3 \pm 0.9$ & $17.0 \pm 0.8$ & $13.7 \pm 0.8$ & $14.1 \pm 0.9$ \\
\hline $\mathrm{Ce}$ & $31.8 \pm 0.8$ & $53 \pm 1$ & $43 \pm 1$ & $41 \pm 1$ & $38 \pm 0.9$ & $40 \pm 1$ \\
\hline $\mathrm{Nd}$ & ND & ND & ND & ND & ND & ND \\
\hline $\mathrm{Sm}$ & $4.1 \pm 0.1$ & $6.5 \pm 0.1$ & $5.6 \pm 0.1$ & $5.3 \pm 0.1$ & $4.8 \pm 0.1$ & $4.7 \pm 0.1$ \\
\hline $\mathrm{Eu}$ & $0.54 \pm 0.11$ & $1.30 \pm 0.1$ & $1.00 \pm 0.09$ & $0.92 \pm 0.12$ & $0.89 \pm 0.11$ & $0.99 \pm 0.10$ \\
\hline Dy & $2.4 \pm 0.2$ & $3.6 \pm 0.3$ & $3.0 \pm 0.3$ & $3.5 \pm 0.4$ & $2.7 \pm 0.3$ & $2.3 \pm 0.3$ \\
\hline $\mathrm{Lu}$ & $0.29 \pm 0.07$ & $0.36 \pm 0.07$ & $0.22 \pm 0.07$ & $0.26 \pm 0.07$ & $0.28 \pm 0.06$ & $0.28 \pm 0.07$ \\
\hline Th & $1.5 \pm 0.1$ & $2.5 \pm 0.1$ & $2.1 \pm 0.1$ & $2.1 \pm 0.1$ & $1.8 \pm 0.1$ & $2.0 \pm 0.1$ \\
\hline $\mathrm{U}$ & $3.1 \pm 1.1$ & $3.8 \pm 0.99$ & $6.0 \pm 1.2$ & $5.5 \pm 1.1$ & $4.7 \pm 1.0$ & $3.4 \pm 1.1$ \\
\hline \multicolumn{7}{|l|}{$(\mathrm{Bq} / \mathrm{g})$} \\
\hline${ }^{40} \mathrm{~K}$ & $0.64 \pm 0.10$ & $0.47 \pm 0.07$ & $0.63 \pm 0.09$ & $0.49 \pm 0.10$ & $0.40 \pm 0.07$ & $0.30 \pm 0.09$ \\
\hline${ }^{137} \mathrm{Cs}$ & $5.69 \pm 0.05$ & $2.00 \pm 0.02$ & $4.87 \pm 0.04$ & $5.58 \pm 0.04$ & $4.23 \pm 0.03$ & $3.31 \pm 0.03$ \\
\hline${ }^{210} \mathrm{~Pb}$ & $3.92 \pm 0.06$ & $0.79 \pm 0.03$ & $2.75 \pm 0.05$ & $1.64 \pm 0.05$ & $1.04 \pm 0.04$ & $0.81 \pm 0.05$ \\
\hline${ }^{226} \mathrm{Ra}$ & $0.15 \pm 0.10$ & $0.31 \pm 0.06$ & $0.44 \pm 0.09$ & $0.54 \pm 0.09$ & $0.36 \pm 0.07$ & $0.43 \pm 0.08$ \\
\hline 1964 & Jul & Aug & Sep & Oct & Nov & Dec \\
\hline \multicolumn{7}{|l|}{$(\mathrm{mg} / \mathrm{g})$} \\
\hline $\mathrm{Si}$ & 219 & 200 & 205 & 185 & 185 & 173 \\
\hline $\mathrm{Al}$ & 69.6 & 66.1 & 68.6 & 49.8 & 55.4 & 50.1 \\
\hline $\mathrm{Fe}$ & 45.7 & 37.1 & 35.2 & 51.5 & 40.9 & 51.7 \\
\hline $\mathrm{Mg}$ & 16.1 & 34.4 & 34.3 & 42.6 & 41.1 & 35.5 \\
\hline $\mathrm{Ca}$ & 57.4 & 90.8 & 58.2 & 76.0 & 64.2 & 72.1 \\
\hline $\mathrm{Na}$ & 22.3 & 26.4 & 42.6 & 36.2 & 44.5 & 42.1 \\
\hline $\mathrm{K}$ & 14.9 & 16.4 & 14.4 & 16.6 & 17.9 & 16.6 \\
\hline $\mathrm{Ti}$ & 4.2 & 3.3 & 4.4 & 2.8 & 2.9 & 3.1 \\
\hline $\mathrm{Mn}$ & 0.5 & 0.7 & 0.7 & 1.6 & 1.1 & 1.1 \\
\hline \multicolumn{7}{|l|}{$(\mu \mathrm{g} / \mathrm{g})$} \\
\hline $\mathrm{Sc}$ & $8.3 \pm 0.2$ & $7.8 \pm 0.2$ & $5.5 \pm 0.1$ & $7.2 \pm 0.1$ & $8.3 \pm 0.2$ & $8.1 \pm 0.2$ \\
\hline $\mathrm{La}$ & $11.2 \pm 0.6$ & $11.1 \pm 0.7$ & $8.0 \pm 0.6$ & $10.7 \pm 0.7$ & $11.2 \pm 0.9$ & $12.1 \pm 0.9$ \\
\hline $\mathrm{Ce}$ & $32 \pm 1$ & $27 \pm 1$ & $22 \pm 0.8$ & $20 \pm 1$ & $25 \pm 1$ & $25 \pm 1$ \\
\hline $\mathrm{Nd}$ & ND & ND & ND & ND & ND & ND \\
\hline $\mathrm{Sm}$ & $4.5 \pm 0.1$ & $4.3 \pm 0.1$ & $2.8 \pm 0.1$ & $3.9 \pm 0.1$ & $3.9 \pm 0.1$ & $4.0 \pm 0.1$ \\
\hline $\mathrm{Eu}$ & $0.88 \pm 0.09$ & $0.77 \pm 0.06$ & $0.60 \pm 0.06$ & $0.76 \pm 0.1$ & $0.85 \pm 0.10$ & $0.85 \pm 0.08$ \\
\hline Dy & $2.1 \pm 0.3$ & $2.6 \pm 0.5$ & $1.4 \pm 0.3$ & $2.0 \pm 0.3$ & N.D. & $2.2 \pm 0.6$ \\
\hline $\mathrm{Lu}$ & $0.14 \pm 0.06$ & $0.23 \pm 0.06$ & $0.21 \pm 0.07$ & $0.28 \pm 0.07$ & $0.17 \pm 0.08$ & $0.18 \pm 0.07$ \\
\hline Th & $1.9 \pm 0.09$ & $1.7 \pm 0.09$ & $1.1 \pm 0.1$ & $1.4 \pm 0.1$ & $1.5 \pm 0.1$ & $0.9 \pm 0.09$ \\
\hline U & $2.4 \pm 1.2$ & ND & $4.1 \pm 1.2$ & ND & ND & ND \\
\hline \multicolumn{7}{|l|}{$(\mathrm{Bq} / \mathrm{g})$} \\
\hline${ }^{40} \mathrm{~K}$ & $0.33 \pm 0.04$ & $0.41 \pm 0.05$ & $0.52 \pm 0.11$ & $0.48 \pm 0.11$ & $0.62 \pm 0.11$ & $0.65 \pm 0.14$ \\
\hline${ }^{137} \mathrm{Cs}$ & $0.24 \pm 0.01$ & $0.47 \pm 0.01$ & $0.82 \pm 0.02$ & $1.11 \pm 0.02$ & $2.20 \pm 0.03$ & $2.24 \pm 0.04$ \\
\hline${ }^{210} \mathrm{~Pb}$ & $0.16 \pm 0.02$ & $0.12 \pm 0.02$ & $0.81 \pm 0.06$ & $1.07 \pm 0.05$ & $1.98 \pm 0.06$ & $3.16 \pm 0.08$ \\
\hline${ }^{226} \mathrm{Ra}$ & $0.24 \pm 0.03$ & $0.16 \pm 0.04$ & $0.39 \pm 0.10$ & $0.34 \pm 0.09$ & $0.20 \pm 0.10$ & $0.18 \pm 0.15$ \\
\hline
\end{tabular}

" \pm " is given as the error in gamma-ray measurements. "ND" means "not detected". 
(b)

\begin{tabular}{|c|c|c|c|c|c|c|}
\hline 2000 & Jan & Feb & Mar & Apr & May & Jun \\
\hline \multicolumn{7}{|l|}{$(\mathrm{mg} / \mathrm{g})$} \\
\hline $\mathrm{Si}$ & - & - & 251 & 545 & 332 & - \\
\hline $\mathrm{Al}$ & - & - & 21.7 & 73.6 & 60.7 & - \\
\hline $\mathrm{Fe}$ & - & - & 4.0 & 28.6 & 31.1 & - \\
\hline $\mathrm{Mg}$ & - & - & 13.6 & 13.7 & 20.2 & - \\
\hline $\mathrm{Ca}$ & - & - & 276 & 68.7 & 124 & - \\
\hline $\mathrm{Na}$ & - & - & 50.3 & 50.8 & 45.0 & - \\
\hline K & - & - & 26.0 & 26.2 & 23.2 & - \\
\hline $\mathrm{Ti}$ & - & - & 0.6 & 3.4 & 2.6 & - \\
\hline $\mathrm{Mn}$ & - & - & 0.7 & 1.0 & 1.0 & - \\
\hline \multicolumn{7}{|l|}{$(\mu \mathrm{g} / \mathrm{g})$} \\
\hline $\mathrm{Sc}$ & $4.03 \pm 0.08$ & $6.9 \pm 0.1$ & $4.75 \pm 0.09$ & $4.98 \pm 0.1$ & $4.58 \pm 0.09$ & - \\
\hline $\mathrm{La}$ & $10.1 \pm 0.4$ & $18.3 \pm 0.8$ & $15.8 \pm 0.8$ & $15.5 \pm 0.5$ & $15.2 \pm 0.6$ & - \\
\hline $\mathrm{Ce}$ & $20.2 \pm 0.9$ & $35 \pm 1$ & $28.4 \pm 0.9$ & $26.0 \pm 0.7$ & $27.2 \pm 0.8$ & - \\
\hline $\mathrm{Nd}$ & $4.5 \pm 3.2$ & $10 \pm 3$ & $13 \pm 3$ & $6.4 \pm 2.9$ & $3.3 \pm 2.8$ & - \\
\hline $\mathrm{Sm}$ & $0.74 \pm 0.03$ & $1.13 \pm 0.03$ & $1.04 \pm 0.02$ & $0.97 \pm 0.02$ & $1.13 \pm 0.02$ & - \\
\hline $\mathrm{Eu}$ & $0.41 \pm 0.05$ & $0.68 \pm 0.05$ & $0.42 \pm 0.05$ & $0.53 \pm 0.05$ & $0.42 \pm 0.05$ & - \\
\hline Dy & $1.8 \pm 0.6$ & $2.8 \pm 0.4$ & $1.5 \pm 0.4$ & $0.6 \pm 0.55$ & $2.0 \pm 0.3$ & - \\
\hline $\mathrm{Lu}$ & $0.10 \pm 0.09$ & $0.11 \pm 0.04$ & $0.22 \pm 0.08$ & ND & $0.16 \pm 0.06$ & - \\
\hline Th & $2.1 \pm 0.1$ & $3.8 \pm 0.1$ & $3.3 \pm 0.1$ & $3.1 \pm 0.1$ & $3.4 \pm 0.1$ & - \\
\hline $\mathrm{U}$ & ND & $2.4 \pm 0.9$ & $3.1 \pm 1.5$ & $2.1 \pm 0.8$ & $3.0 \pm 1.2$ & - \\
\hline \multicolumn{7}{|l|}{$(\mathrm{Bq} / \mathrm{g})$} \\
\hline${ }^{40} \mathrm{~K}$ & $2.1 \pm 0.6$ & $0.91 \pm 0.05$ & $1.7 \pm 0.4$ & $1.1 \pm 0.4$ & $1.6 \pm 0.5$ & $13 \pm 11$ \\
\hline${ }^{137} \mathrm{Cs}$ & ND & ND & ND & ND & ND & ND \\
\hline${ }^{210} \mathrm{~Pb}$ & $29.5 \pm 0.4$ & $11.5 \pm 0.3$ & $10.5 \pm 0.2$ & $6.6 \pm 0.2$ & $7.5 \pm 0.3$ & $82 \pm 6$ \\
\hline${ }^{226} \mathrm{Ra}$ & ND & ND & ND & ND & ND & ND \\
\hline 2000 & Jul & Aug & Sep & Oct & Nov & Dec \\
\hline \multicolumn{7}{|l|}{$(\mathrm{mg} / \mathrm{g})$} \\
\hline $\mathrm{Si}$ & - & - & 489 & - & 531 & - \\
\hline $\mathrm{Al}$ & - & - & 74.8 & - & 65.9 & - \\
\hline $\mathrm{Fe}$ & - & - & 37.4 & - & 34.9 & - \\
\hline $\mathrm{Mg}$ & - & - & 12.7 & - & 26.7 & - \\
\hline $\mathrm{Ca}$ & - & - & 77.2 & - & 57.6 & - \\
\hline $\mathrm{Na}$ & - & - & 46.7 & - & 50.8 & - \\
\hline K & - & - & 24.1 & - & 26.2 & - \\
\hline $\mathrm{Ti}$ & - & - & 4.2 & - & 3.4 & - \\
\hline $\mathrm{Mn}$ & - & - & 0.8 & - & 1.0 & - \\
\hline \multicolumn{7}{|l|}{$(\mu \mathrm{g} / \mathrm{g})$} \\
\hline $\mathrm{Sc}$ & - & $4.30 \pm 0.08$ & - & $3.18 \pm 0.06$ & $3.37 \pm 0.06$ & $4.85 \pm 0.09$ \\
\hline $\mathrm{La}$ & - & $17.3 \pm 0.6$ & - & $9.4 \pm 0.5$ & $9.5 \pm 0.4$ & $15.9 \pm 0.7$ \\
\hline $\mathrm{Ce}$ & - & $24.9 \pm 0.6$ & - & $15.8 \pm 0.8$ & $16.3 \pm 0.8$ & $27.7 \pm 0.9$ \\
\hline $\mathrm{Nd}$ & - & $5.4 \pm 3.1$ & - & ND & ND & $13.0 \pm 5$ \\
\hline $\mathrm{Sm}$ & - & $0.89 \pm 0.02$ & - & $0.59 \pm 0.03$ & $0.55 \pm 0.02$ & $0.99 \pm 0.03$ \\
\hline $\mathrm{Eu}$ & - & $0.44 \pm 0.05$ & - & $0.33 \pm 0.05$ & $0.27 \pm 0.05$ & $0.48 \pm 0.05$ \\
\hline Dy & - & $2.3 \pm 0.5$ & - & $0.5 \pm 0.35$ & $1.0 \pm 0.5$ & $1.5 \pm 0.4$ \\
\hline $\mathrm{Lu}$ & - & $0.18 \pm 0.07$ & - & $0.28 \pm 0.08$ & ND & $0.22 \pm 0.07$ \\
\hline $\mathrm{Th}$ & - & $2.6 \pm 0.1$ & - & $1.7 \pm 0.1$ & $1.8 \pm 0.1$ & $3.3 \pm 0.1$ \\
\hline $\mathrm{U}$ & - & $2.2 \pm 0.9$ & - & ND & $0.4 \pm 0.35$ & ND \\
\hline \multicolumn{7}{|l|}{$(\mathrm{Bq} / \mathrm{g})$} \\
\hline${ }^{40} \mathrm{~K}$ & $2.4 \pm 1.5$ & $1.9 \pm 0.7$ & ND & $0.89 \pm 0.81$ & ND & ND \\
\hline${ }^{137} \mathrm{Cs}$ & ND & ND & ND & ND & ND & ND \\
\hline${ }^{210} \mathrm{~Pb}$ & $3.1 \pm 0.8$ & $13.6 \pm 0.4$ & $48 \pm 2$ & $17.4 \pm 0.5$ & $8.9 \pm 0.4$ & $9.9 \pm 0.3$ \\
\hline${ }^{226} \mathrm{Ra}$ & ND & ND & ND & ND & ND & ND \\
\hline
\end{tabular}

" \pm " is given as the error in gamma-ray measurements. "ND" means "not detected". 
Table 2. Yeild of Fukuoka deposits and some meteorological factors at Fukuoka.

\begin{tabular}{|c|c|c|c|c|c|c|}
\hline year & month & yeild $/ \mathrm{g} \cdot \mathrm{m}^{-2}$ & precipitation $/ \mathrm{mm}$ & average humidity $/ \%$ & $\begin{array}{l}\text { average wind } \\
\text { velocity/m }\end{array}$ & $\begin{array}{l}\text { predominant wind } \\
\text { direction }\end{array}$ \\
\hline \multirow{12}{*}{1964} & Jan & 10.82 & 144.5 & 71 & 3.2 & WNW \\
\hline & Feb & 20.20 & 62.1 & 72 & 3.1 & W \\
\hline & Mar & 15.70 & 58.4 & 65 & 3.6 & W \\
\hline & Apr & 13.54 & 183.8 & 82 & 3.1 & $\mathrm{~N}$ \\
\hline & May & 18.42 & 138.6 & 73 & 2.5 & NNE \\
\hline & Jun & 14.60 & 184.4 & 77 & 2.7 & $\mathrm{~N}$ \\
\hline & Jul & 33.30 & 91.7 & 72 & 3.1 & W \\
\hline & Aug & 30.56 & 131.5 & 74 & 3.2 & $\mathrm{~N}$ \\
\hline & Sep & 12.70 & 143.4 & 78 & 2.6 & $\mathrm{~N}$ \\
\hline & Oct & 13.42 & 101.4 & 73 & 2.5 & $\mathrm{~N}$ \\
\hline & Nov & 10.82 & 106.2 & 70 & 2.6 & $\mathrm{~N}$ \\
\hline & Dec & 9.90 & 42.9 & 69 & 2.6 & NNW \\
\hline \multirow{12}{*}{2000} & Jan & 1.39 & 71.0 & 67 & 2.6 & NNW \\
\hline & Feb & 1.57 & 27.0 & 56 & 3.1 & NNW \\
\hline & Mar & 2.32 & 103.5 & 58 & 3.2 & NNW \\
\hline & Apr & 2.04 & 82.5 & 59 & 3.0 & NNW \\
\hline & May & 1.78 & 101.0 & 66 & 2.5 & NNW \\
\hline & Jun & 0.18 & 250.5 & 74 & 2.4 & SSW \\
\hline & Jul & 0.52 & 149.5 & 68 & 2.9 & SSE \\
\hline & Aug & 0.08 & 100.0 & 69 & 2.8 & $\mathrm{~N}$ \\
\hline & Sep & 0.35 & 197.5 & 71 & 2.8 & SSE \\
\hline & Oct & 0.96 & 86.5 & 71 & 2.4 & SSE \\
\hline & Nov & 1.06 & 143.0 & 68 & 2.4 & SSE \\
\hline & Dec & 1.31 & 32.0 & 62 & 2.4 & WNW \\
\hline
\end{tabular}

Table 3. Monthly depositions of uranium in the atmospheric deposits collected at Fukuoka.

\begin{tabular}{ccc}
\hline & \multicolumn{2}{c}{ Monthly deposition $/ \mu \mathrm{g} \cdot \mathrm{m}^{-2}$} \\
\cline { 2 - 3 } Jan & 1964 & 2000 \\
Feb & 34 & - \\
Mar & 77 & 3.8 \\
Apr & 94 & 7.2 \\
May & 75 & 4.3 \\
Jun & 87 & 5.3 \\
Jul & 50 & - \\
Aug & 80 & - \\
Sep & - & 0.2 \\
Oct & 52 & - \\
Nov & - & 0.5 \\
Dec & - & - \\
\hline
\end{tabular}

the difference in the origin of mineral dusts contained in the deposits. The Fukuoka deposits in 2000 are expected to be mainly composed of dusts from the East Asia, because the $\mathrm{Th} / \mathrm{Sc}$ and $\mathrm{La} / \mathrm{Lu}$ values of the deposits are comparable with those of loess in the Loess Plateau, China [11]. The relative high Si/Al ratio and Ca content in the deposits in 2000 compared to those in 1964 (Table 1) is in accordance with the speculation. The $\mathrm{Si} / \mathrm{Al}$ ratio in the Fukuoka deposits in 2000 is obviously high compared to that in Japanese igneous rocks, meanwhile the value seems comparable with that in loess and desert sands in China [12].

A principal component analysis using the contents of REEs, Th, $\mathrm{U}$ and $\mathrm{Al}$ in the deposits and the meteorologcal parameters as variables identified the uranium content in the Fukuoka deposits in 1964 as a member of the second principal component together with ${ }^{137} \mathrm{Cs}$ and ${ }^{210} \mathrm{~Pb}$, but not with $\mathrm{Al}$, REEs and $\mathrm{Th}$, whereas the same analysis identified the uranium content as a member of the first principal component together with REEs, Th, precipitation and wind velocity for the deposits in 2000 (Table 4). The first principal component in 2000 
Table 4. Rotated factor matrix for Fukuoka deposits in 1964 and 2000.

\begin{tabular}{|c|c|c|c|c|c|c|}
\hline \multicolumn{4}{|c|}{1964} & \multicolumn{3}{|c|}{2000} \\
\hline & \multicolumn{3}{|c|}{ Factor } & & \multicolumn{2}{|c|}{ Factor } \\
\hline & 1 & 2 & 3 & & 1 & 2 \\
\hline $\mathrm{La}$ & 0.95 & 0.28 & 0.05 & $\mathrm{Sc}$ & 0.92 & 0.10 \\
\hline $\mathrm{Ce}$ & 0.95 & 0.14 & 0.21 & $\mathrm{La}$ & 0.92 & 0.18 \\
\hline $\mathrm{Sm}$ & 0.92 & 0.14 & 0.33 & $\mathrm{Ce}$ & 0.99 & 0.00 \\
\hline $\mathrm{Eu}$ & 0.96 & -0.23 & 0.15 & precipitation & -0.92 & 0.15 \\
\hline Th & 0.95 & 0.02 & 0.24 & ${ }^{210} \mathrm{~Pb}$ & 0.23 & 0.87 \\
\hline Precipitation & -0.26 & 0.26 & -0.85 & wind velocity & 0.76 & 0.20 \\
\hline Wind velocity & 0.18 & 0.41 & 0.84 & $\mathrm{U}$ & 0.76 & -0.35 \\
\hline${ }^{210} \mathrm{~Pb}$ & -0.28 & 0.85 & 0.37 & $\mathrm{Sm}$ & 0.91 & -0.34 \\
\hline${ }^{137} \mathrm{Cs}$ & 0.15 & 0.96 & -0.08 & $\mathrm{Eu}$ & 0.92 & 0.12 \\
\hline $\mathrm{U}$ & 0.35 & 0.62 & -0.08 & Th & 0.94 & -0.31 \\
\hline $\mathrm{Sc}$ & 0.98 & 0.03 & 0.12 & & & \\
\hline $\mathrm{Al}$ & 0.97 & 0.18 & -0.11 & & & \\
\hline Variance (\%) & 55.70 & 20.60 & 15.26 & variance $(\%)$ & 69.76 & 15.45 \\
\hline
\end{tabular}

Extraction method: Principal Component Analysis; Rotation method: Varimac with Kaiser Normalization.

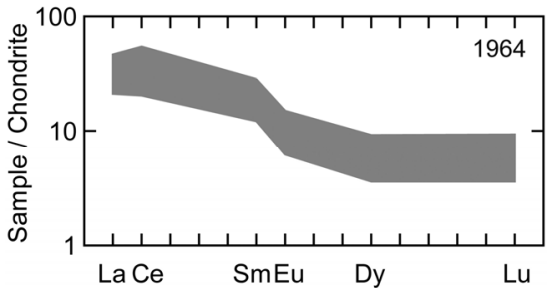

(a)

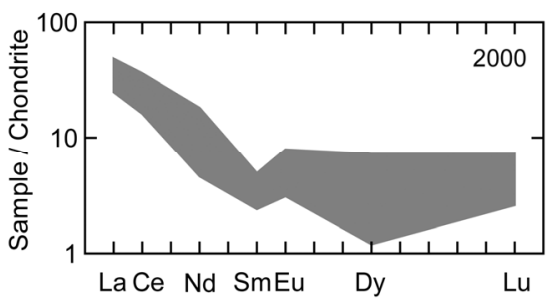

(b)

Figure 3. The chondrite-normalized REE patterns of the Fukuoka deposits in (a) 1964 and (b) 2000. The shaded areas indicate the range of the REE patterns. The shape of the patterns in 2000 shows steeper slope in the range from $\mathrm{La}$ to $\mathrm{Sm}$ relative to that in 1964. There is obvious deference in $\mathrm{Sm} / \mathrm{Eu}$ ratios between the patterns in 1964 and 2000.

suggests the deposition of dust particles resulted from resuspention of surface soils was caused by low precipitation and high wind velocity. The transport mechanism of uranium contained in the atmospheric deposits is thus expected to be different between 1964 and 2000. While enriched uranium probably deposited with anthropogenic

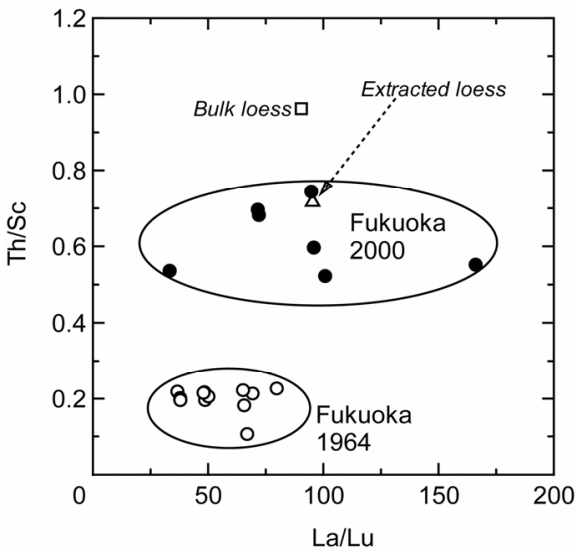

Figure 4. The plots of $\mathrm{Th} / \mathrm{Sc}$ against $\mathrm{La} / \mathrm{Lu}$ for the Fukuoka deposits in 1964 (open circles) and 2000 (closed circles). The open rectangle and triangle show the plots for the bulk and extracted loess samples of the Loess Plateau, China cited from Weber et al. [11], respectively.

radionuclides originating from nuclear test explosions as fallout materials in 1964, resuspended contaminated soils are major sources of enriched uranium contained in atmospheric deposits in these days. In fact, the ${ }^{235} \mathrm{U} /{ }^{238} \mathrm{U}$ ratio in the acid-soluble part of the atmospheric deposit in 1964 is higher than the natural ratio, whereas that in the corresponding acid-insoluble part is regarded as the natural ratio (Figure 2). This finding is associated with the existence of enriched uranium-bearing hot particles originating from nuclear test explosions. In contrast, the ${ }^{235} \mathrm{U} /{ }^{238} \mathrm{U}$ ratio in the acid-insoluble part of the deposit in 
2000 is higher than the natural ratio, suggesting the existence of enriched uranium fused with silicate minerals [4].

Based on the temporal variation of the specific activity of ${ }^{234} \mathrm{Th}$ in atmospheric deposits collected in Osaka, Japan, Matsunami and Mamuro [13] suggested that uranium from nuclear test explosions had been deposited in Japan in the 1970s within two months after the explosions. On the other hand, the maximum annual deposition of ${ }^{239,240} \mathrm{Pu}$ was observed in 1963 just after the large scale nuclear test explosions in 1961-1962 [14]. The estimated mean residence times of plutonium ejected into the atmosphere by nuclear tests in the stratosphere and in the troposphere are 1.7 years [15] and 71 days [16], respectively. Since both uranium and plutonium are used in nuclear explosives and are refractory elements differently from volatile elements like cesium, the two must have shown similar behaviors on global fallout. Thus, in 1964, significant amounts of uranium with enriched uranium probably deposited with anthropogenic radionuclides as fallout materials after the 1961-1962 large scale nuclear tests conducted by US and former USSR.

\section{CONCLUSION}

The ${ }^{235} \mathrm{U} /{ }^{238} \mathrm{U}$ ratios in atmospheric deposits collected between 1964 and 2000 at Fukuoka located in southwest Japan were slightly higher than the natural ratio. A remarkable amount of enriched uranium might have been deposited as fallout directly from nuclear test explosions in the 1960s. In the present days, enriched uranium has presumably been deposited as resuspention of surface soils in the East Asian deserts and arid regions which have been contaminated with fused silicates originating from nuclear test sites.

\section{ACKNOWLEDGEMENTS}

This work was supported by JSPS Grant-in-Aid for challenging Exploratory Research 21651008 and the Inter University Program for the Common Use of JAEA Facilities. We thank Mr. A. Kitahara (Musashi Institute of Technology) for his support in neutron activation analysis.

\section{REFERENCES}

[1] Weyer, S., Anbar, A.D., Gerdes, A., Gordon, G.W., Algeo, T.J. and Boyle, E.A. (2008) Natural fractionation of ${ }^{235} \mathrm{U} /{ }^{238} \mathrm{U}$. Geochimica et Cosmochimica Acta, 72, 345359. doi:10.1016/j.gca.2007.11.012

[2] Warneke, T., Croudace, I.W., Warwick, P.E. and Taylor, R.N. (2002) A new ground-level fallout record of uranium and plutonium isotopes for northern temperate latitudes. Earth and Planetary Science Letters, 203, 1047-

\section{7. doi:10.1016/S0012-821X(02)00930-5}

[3] Meteorological Research Institute (1996) Geochemical studies and analytical methods of anthropogenic radionuclides in fallout samples. Technical Report of the Meteorological Research Institute No. 36.

[4] Kikawada, Y., Oda, K., Yamauchi, R., Nomura, M., Honda, T., Oi, T., Hirose, K. and Igarashi, Y. (2009) Anomalous uranium isotope ratio in atmospheric deposits in Japan. Journal of Nuclear Science and Technology, 46, 10941098. doi:10.1080/18811248.2009.9711621

[5] Uchida, T. (1986) Sample digestion using Teflon sealed container. Bunseki, 1986, 71-77.

[6] Kitahara, A., Honda, T., Hirose, K., Igarashi, Y. and Aoyama, M. (2005) Study on uranium, thorium and fission products of deposition samples collected at Fukuoka in 1964. Fission Track News Letter, 18, 41-45.

[7] Taylor, S.R., McLennan, S.M. and McCulloch, M.T. (1983) Geochemistry of loess, continental crustal composition and crustal model ages. Geochimica et Cosmochimica Acta, 47, 1897-1905. doi:10.1016/0016-7037(83)90206-5

[8] Taylor, S.R. and McLennan, S.M. (1985) The continental crust: Its composition and evolution. Blackwell Scientific Publications Ltd., Oxford.

[9] Masuda, A., Nakamura, N. and Tanaka, T. (1973) Fine structures of mutually normalized rare-earth patterns of chondrites. Geochimica et Cosmochimica Acta, 37, 239-248. doi:10.1016/0016-7037(73)90131-2

[10] Masuda, A. (1975) Abundance of monoisotopic REE, consistent with the Leedey chondrite values. Geochemical Journal, 9, 183-184. doi:10.2343/geochemj.9.183

[11] Weber II, E.T., Owen, R.M., Dickens, G.R. and Rea, D.K. (1998) Causes and implications of the middle rare earth element depletion in the eolian component of North $\mathrm{Pa}$ cific sediment. Geochimica et Cosmochimica Acta, 62, 1735-1744. doi:10.1016/S0016-7037(98)00102-1

[12] Furukawa, M., Akata, N., Zhuo, W., Guo, Q., Narazaki, N. and Tokonami, S. (2005) Characteristics on natural radioactivity of loess and eolian dust origin soils in East Asia. Journal of Aerosol Research, 20, 306-312.

[13] Matsunami, T. and Mamuro, T. (1975) Study of uranium deposition by basin method. Annual Report of the Radiation Center of Osaka Prefecture, 16, 22-24.

[14] Hirose, K., Igarashi, Y., Aoyama, M. and Miyao, T. (2001) Long-term trends of plutonium fallout observed in Japan. In: Kudo, A., Ed., Plutonium in the Environment, Elsevier, Amsterdam, 251-266.

[15] Miyake, Y., Katsuragi, Y. and Sugimura Y. (1968) Deposition of plutonium in Tokyo through the end of 1966. Papers in Meteorology and Geophysics, 19, 267-276.

[16] Holloway, R.W. and Hayes, D.W. (1982) Mean residence time of plutonium in the troposphere. Environmental Science \& Technology, 16, 127-129. doi:10.1021/es00096a015. 